\title{
Nagrobek Stanisława Staszica a polityka wizerunkowa Towarzystwa Warszawskiego Przyjaciół Nauk
}

\section{Stanisław Staszic's Tombstone and the Image-Building Policy of the Warsaw Society of Friends of Sciences}

The article is devoted to the artistic setting of Stanisław Staszic's (1755-1826) burial place, for which his main heir, the Warsaw Royal Society of the Friends of Sciences (TKWPN), was responsible. The inspiration to raise this topic was the discovery of two previously unknown Jakub Tatarkiewicz's designs of Staszic's unrealized neoclassical tombstone in the collections of the Central Archives of Historical Records in Warsaw (AGAD). However, the projects were never commissioned by TKWPN but were the sculptor's proposal. By analysing the relationship between these artistic projects and the initiatives concerning Staszic's tomb which stemmed directly from the Society (a big raw stone as memorial), the article highlights the problem of TKWPN's participation in creating the posthumous cult of its long-time president and most important benefactor. The TKWPN's seemingly paradoxical reluctance to glorify Staszic by means of traditional (artistic) forms of commemoration can be interpreted as a logical action calculated to benefit the Society's image. Therefore, focusing on this single aspect of the posthumous cult of Staszic, directly related to the TKWPN, this article refers to the image-building policy of this institution, and thus to the ways of building its social status. At the same time, it tackles the issue of the prestige of science and scientific patronage as a new (from the early $19^{\text {th }}$-century perspective) form of public merit.

Keywords: Stanisław Staszic, Warsaw, memorial, tombstone, commemoration, elite, learned society

Słowa kluczowe: Stanisław Staszic, Warszawa, pomnik, nagrobek, upamiętnienie, elita, towarzystwo naukowe

\section{Projekt Tatarkiewicza}

W zespole Towarzystwa Królewskiego Warszawskiego Przyjaciół Nauk (TKWPN) w Archiwum Głównym Akt Dawnych w Warszawie, w pliku dokumentów z pozoru dotyczących 
jedynie budowy pomnika Mikołaja Kopernika, zachowały się dwa niepowiązane z tym tematem pisma Jakuba Tatarkiewicza z 1827 r., wraz z załączonymi projektami nagrobka Stanisława Staszica (Ryc. 1, 2), zmarłego rok wcześniej prezesa Towarzystwa1. Oba listy mają datę 17 września i były pisane w Rzymie, w okresie, w którym ten warszawski artysta przebywał na stypendium rządu Królestwa Polskiego, szkoląc się pod okiem Bertela Thorvaldsena ${ }^{2}$. Z pierwszego pisma, adresowanego wprost do Towarzystwa, dowiadujemy się, że Tatarkiewicz sam wyszedł z tą propozycją, bez niczyjej zachęty czy zlecenia. Powoływał się jedynie na intuicyjną

pewność [...] iż cały naród, a szczególniej Prześwietne Towarzystwo ma zamiar oddać ostatnią przysługę tyle czcigodnemu i zasłużonemu w ojczyźnie mężowi [...] w wystawieniu mu nagrobka.

Przesyłał więc dwa rysunki spośród „kilku” (brak informacji o innych wersjach) opracowanych przez siebie „pomysłów”, oferując zarazem, że mógłby też przesłać ich gipsowe modele. Miało to istotne znaczenie, jako że w obu przypadkach Tatarkiewicz proponował wystawić pomnik wolnostojący, czyli dający się obejść dookoła. Na czworobocznym cokole przednia ściana byłaby pozostawiona na inskrypcję, podczas gdy trzy pozostałe służyłyby ukazaniu „w płaskorzeźbach najznaczniejszych czynów tego Męża podług wybranych przedmiotów przez Prześ[wietne] Towarzystwo”. Całość miano obłożyć „czarnym lub kolorowym ciemnym" marmurem krakowskim, z wyjątkiem tablic z płaskorzeźbami, tablicy inskrypcyjnej oraz wieńczącej całość rzeźby. Tatarkiewicz proponował wykonać te pozostałe elementy w marmurze białym.

Cokoły, luźno inspirowane modelem tzw. nagrobka neronowego z Via Cassia w Rzymie (z akroterionami na rogach), były w zasadzie takie same w obu wariantach. Różnicowały je tylko płaskorzeźbione detale, w jednym przypadku ukazujące wieniec laurowy ze wstęgą, a w drugim uskrzydloną klepsydrę. Była to dość obiegowa symbolika sepulkralna, charakterystyczna dla klasycystycznego repertuaru, również w ówczesnej Warszawie ${ }^{3}$. Większą oryginalnością odznaczały się ustawione powyżej pełnopostaciowe posągi. Pierwszy ukazywał Geniusza Śmierci pod postacią nagiego mężczyzny ze skrzydłami, wspartego na odwróconej do dołu pochodni, a zarazem przytrzymującego medalion z popiersiem Staszica, który opierał się o grzbiet leżącego Iwa. Drugi ukazywał personifikację Religii pod postacią kobiety. Była ona przepasana wstęgą z napisem „RELIGIA” i przykryta welonem, prawą ręką obejmując pokaźnych rozmiarów krzyż. Obie rzeźby mogły być bezpośrednio inspirowane dekoracją słynnego rzymskiego grobowca papieża Klemensa XIII w bazylice św. Piotra na Watykanie, który został ukończony w 1792 r. przez Antonia Canovę (Ryc. 3). Zdobią go bowiem analogiczne personifikacje Religii (względnie Wiary) oraz Geniusz Śmierci, nie

1 Archiwum Główne Akt Dawnych [AGAD], zesp. Towarzystwo Królewskie Warszawskie Przyjaciół Nauk, sygn. 56, akta tyczące się wystawienia pomnika dla Kopernika, t. 2, pismo Tatarkiewicza do TKWPN z 17 IX 1827 r., s. 83-84, 87; pismo Tatarkiewicza do ks. Czarneckiego z 17 IX 1827 r., s. 85-86.

2 Na temat pobytu Tatarkiewicza w Rzymie zob. W. Tatarkiewicz, Rzeźbiarz polskiego klasycyzmu, [w:] idem, O sztuce polskiej XVII i XVIII wieku: architektura i rzeźba, Warszawa 1966, s. 479-481.

3 Na temat sepulkralnych motywów dekoracyjnych w Warszawie tego okresu (na przykładzie cmentarza powązkowskiego) zob. T.M. Rudkowski, Cmentarz Powązkowski w Warszawie. Panteon Polski, Wrocław 2006, s. 87-98.

4 Posąg kobiety z nagrobka Klemensa XIII można też intepretować jako symbol jednej z trzech cnót teologicznych, czyli Wiary - personifikacje Nadziei i Miłości znajdują się na sarkofagu. 
mówiąc o lwie (a właściwie parze lwów) i podobnym sarkofagu ${ }^{5}$. Wprawdzie wszystkie te elementy miały dawniejsze wzorce i stanowiły dość tradycyjne motywy w ówczesnej sztuce sepulkralnej, wspomniany monument Canovy jako bodaj jedyny w ówczesnym Rzymie łączył je ze sobą w jednym dziele. Fakt, że Tatarkiewicz był uczniem jego konkurenta nie miał raczej w tym przypadku poważniejszego znaczenia. Watykański grobowiec był publicznie dostępny, znajdując się w jednym z najważniejszych kościołów Wiecznego Miasta, przez niektórych uznawany był również za najlepsze dzieło tego mistrza ${ }^{6}$. Dodajmy, że w okresie projektowania nagrobka Staszica przez Tatarkiewicza, Thorvaldsen pracował nad sepulkralnym monumentem Włodzimierza Potockiego, fundowanym przez rodzinę z przeznaczeniem dla katedry krakowskiej. Jego głównym akcentem była jednak pełnopostaciowa (ponadnaturalnej wielkości) figura zmarłego, a elementy symboliczne odgrywały drugorzędną rolę (postać Geniusza Śmierci została umieszczona w formie płaskorzeźby na cokole $)^{7}$. Z jego wcześniejszych „polskich” prac warto wymienić też relief zdobiący Iwowski nagrobek Józefy z Olizarów Dunin-Borkowskiej. On również wyraźnie odbiegał od koncepcji Tatarkiewicza. Ta stosunkowo niewielka płyta ukazywała zmarłą, prowadzoną przez Geniusza Śmierci i podążającego za nimi zrozpaczonego syna8.

W przypadku monumentu Klemensa XIII posągi Religii i Geniusza Śmierci reprezentowały wzajemną relację sacrum i profanum, transcendencji i doczesności, co było podkreślone przez dwa towarzyszące tym przedstawieniom Iwy, z których ten przy Geniuszu Śmierci spał, natomiast drugi, leżący u stóp Religii, był czujny, symbolizując życie po śmierci. Natomiast Tatarkiewicz pozostawiał Towarzystwu wybór pomiędzy religijną i świecką interpretacją śmierci Staszica. Mogło to być motywowane podwójnym charakterem życia zmarłego, który - mimo że został wyświęcony na księdza (i nigdy formalnie nie opuścił stanu duchownego) - prowadził się na sposób świecki. Wprawdzie przypadek Staszica równie dobrze mógł zachęcać do uwzględnienia zarówno religijnego, jak i świeckiego sposobu rozumienia śmierci w symbolicznej dekoracji jego grobu. O braku bardziej złożonej kompozycji wśród proponowanych projektów zadecydowały jednak zapewne przede wszystkim względy finansowe. Starając się zachęcić Towarzystwo do zlecenia mu pracy nad tym nagrobkiem, Tatarkiewicz we wspomnianym piśmie nie tylko bowiem podkreślał swoje umiejętności rzeźbiarskie. Deklarował również, że będzie starać się „jak za najmniejszą cenę uskutecznić” ten projekt, a ponadto „odstąpi z własnego zarobku cząstkę składki ogólnej". Dla porównania zaznaczmy, że oprócz wspomnianego pomnika Potockiego w tym samym czasie inny rzymski rzeźbiarz, Francesco Massimiliano Laboureur, pracował nad wielką, trójfigurową grupą upamiętniająca marszałka sejmu wielkiego Stanisława Małachowskiego. Monument, zamówiony przez krewnych, był początkowo przeznaczony do kościoła św. Krzyża w Warszawie, ostatecznie jednak w 1830 r. stanął w katedrze św. Jana?.

Trudno oczywiście zakładać, że inicjatywa Tatarkiewicza nie miała nic wspólnego z patriotyzmem, a zwłaszcza z poczuciem społecznej odpowiedzialności, jaka spoczywała na

5 Na temat papieskiego grobowca zob. np.: Ch.M.J. Johns, Ecclesiastical Politics and Papal Tombs: Antonio Canova's Monuments to Clement XIV and Clement XIII, „The Sculpture Journal” t. 2, 1998, s. 58-71.

6 Zob. S. Dunin-Borkowski, Podróż do Włoch w latach 1815 i 1816, Warszawa 1820, s. 266.

7 K. Mikocka-Rachubowa, Rzeźba włoska w Polsce około 1770-1830. Katalog, Warszawa 2016, s. 137-144.

8 Ibid., s. 111-112.

9 Ibid., s. 343-351. 
artyście kształcącym się za publiczne pieniądze. Zachowana korespondencja sugeruje jednak, że przede wszystkim miała ona mu zapewnić prestiżowe zlecenie, pomagające w rozwijaniu krajowej kariery po powrocie z pięcioletniego pobytu za granicą, który właśnie dobiegał końca (na początku kolejnego roku rząd Królestwa wezwał Tatarkiewicza do Warszawy ${ }^{10}$ ). Rezygnacja z zarobku była w tym przypadku decyzją w pełni racjonalną, pojmowaną jako inwestycja we własną sławę, którą mógł zapewnić nagrobek tak powszechnie szanowanej postaci, zajmującej wysokie stanowiska państwowe i zarazem przewodzącej jednej z najważniejszych instytucji publicznych o charakterze społecznym (Towarzystwo formalnie pozostawało niezależne od rządu, choć było z nim blisko związane personalnie, nie tylko przez osobę Staszica ${ }^{11}$ ). Dobrze o tym świadczy drugi list Tatarkiewicza, skierowany do sekretarza Towarzystwa, Edwarda Czarneckiego, który był jego dawnym szkolnym nauczycielem ${ }^{12}$. Opisując swoje postępy w sztuce rzeźbiarskiej, które zawdzięczał pobytowi w Rzymie, i licząc na jego protekcję ze względu na dawną znajomość, Tatarkiewicz zwierzał się ze swojego planu wykonania „jeżeli nie statui, to przynajmniej portretów w marmurze" szeregu "ludzi sławnych Polaków i zasłużonych w nauce". Nie będąc jednak w stanie samemu ryzykować takiego przedsięwzięcia, które wymagało znacznych nakładów bez obietnicy uzyskania ich zwrotu (nie mówiąc o zarobku), wyrażał nadzieję, „iż w przyszłości zjedna sobie zaufanie rządowe w powierzeniu mu tyle dla niego miłych dzieł". Nie tylko wspominał o zleconym mu niedawno popiersiu księcia Józefa Poniatowskiego, ale i również właśnie „w tej myśli” posyłał projekty nagrobka Staszica. W wyobrażeniu Tatarkiewicza ten ostatni mógł zapewne stanowić punkt wyjścia jego przyszłej kariery na stanowisku niejako oficjalnego rzeźbiarza Królestwa, zajmującego się upamiętnianiem wybitnych jednostek (a więc tą specyficzną dziedziną sztuk pięknych, która cieszyła się wówczas znacznym prestiżem ze względu na swoją rolę społeczną) $)^{13}$.

Pomimo publicznego charakteru tego przedsięwzięcia, symboliczna forma, jaką rzeźbiarz chciał nadać nagrobnemu pomnikowi Staszica, odznaczała się bardziej prywatnymi niż oficjalnymi konotacjami. Zamiast podkreślać publiczne zasługi zmarłego, była skupiona na samym fakcie śmierci. Całkiem prawdopodobne, że na takim sposobie opracowania obu projektów zaważyła wiedza rzeźbiarza o strategii „przyjaciół nauk” względem upamiętnienia dawnego prezesa, zgodnie z jego własną wolą powstrzymujących się od jego pośmiertnej gloryfikacji. Władze Towarzystwa nie zdecydowały się jednak podjąć inicjatywy Tatarkiewicza. Wprawdzie nieznana jest treść odpowiedzi ${ }^{14}$, musiała być ona odmowna, skoro nie wrócono już do tego tematu w przyszłości. Aby zrozumieć przyczyny, dla których tak się stało, należy przyjrzeć się bliżej działaniom samego Towarzystwa w zakresie upamiętnienia swojego zasłużonego prezesa.

10 W. Tatarkiewicz, op. cit., s. 481.

11 Zob. J. Michalski, Z dziejów Towarzystwa Przyjaciół Nauk, Warszawa 1953, s. 98.

12 AGAD, Pismo Tatarkiewicza do ks. Czarneckiego, s. 85-86.

13 Zob. np.: S. Sierakowski, Architektura obejmująca wszelki gatunek murowania $i$ budowania, t. 1, Kraków 1812, s. 218; F. Pancer, Myśli o piękności w Architekturze (Dokończenie), „Pamiętnik Warszawski Umiejętności Czystych i Stosowanych" t. 3, 1829, s. 236.

14 Adnotacja „postanowiono odpisać Wars: 7/10 27” na pierwszej stronie pisma Tatarkiewicza do TKWPN. AGAD, pismo Tatarkiewicza do TKWPN, s. 1. 
Śmierć Staszica w styczniu 1826 r. odbiła się szerokim echem w stolicy konstytucyjnego Królestwa Polskiego. Prasa warszawska donosiła wówczas o

nader dotkliwej stracie [którą] poniosła Polska przez zgon [...] ministra stanu, dyrektora generalnego przemysłu i kunsztów, prezesa Towarzystwa Króle[wskiego] Warsz[awskiego] Przyjaciół Nauk, kawalera orderów Orła Białego i Ś[więtego] Stanisława I. klasy, wzoru gorliwości obywatelskiej, opiekuna kunsztów i nauk, dobroczyńcy cierpiącej ludzkości.

Zgodnie z nekrologiem (którego treść mogła pochodzić od TKWPN jako spadkobiercy zmarłego), to właśnie Towarzystwo, „któremu tak długo przewodniczył, które wspierał, któremu tak wspaniały wystawił przybytek", miało w pierwszym rzędzie „świadczyć [...] przez długie lata o życiu Stanisława Staszica"15. Przy okazji pogrzebu podnoszono jednak kwestię paradoksalnej skromności pośmiertnych hołdów, wymaganych przez zmarłego w testamencie - pogrzeb miał być bowiem „skromny, nie różniący się od pogrzebu chrześcijanina ubogiego"16. „Przyjaciele nauk” jako organizatorzy tej uroczystości ewidentnie starali się uczynić zadość woli prezesa, co nie umknęło uwadze żałobników, określających ceremonię jako „suto-ubogą"17. Wrażenie „sutości” zawdzięczała ona przede wszystkim tłumowi żałobników, czyli „całą milę za szanownymi zwłokami postępujących pieszo licznych wielbicieli cnót nieboszczyczka, znakomitych urzędników, profesorów, uczniów, zgoła mieszkańców wszelkiego stanu"18. Dodajmy, że była to pora „trzaskającego mrozu", w środku zimy ${ }^{19}$. Przemawiający wówczas w imieniu Towarzystwa Fryderyk Skarbek zauważał, że choć „żądał Staszic w oświadczeniu ostatniej woli swojej, aby pogrzeb jego nie różnił się niczym od pogrzebu ubogiego chrześcijanina”, jego „skromność nie dozwoliła mu przewidzieć, że pogrzeb ten będzie świetnym i pamiętnym z powodu hołdu czci ostatniej przez tylu ziomków jego zasłudze oddanego"20.

Wyrazem chęci Staszica do zachowania skromnego charakteru pogrzebu był również sam wybór miejsca pochówku, czyli eremu kamedulskiego w podwarszawskich Bielanach. Niezwiązany bezpośrednio z Towarzystwem, a reprezentujący władze rządowe Albert (Wojciech) Grzymała, w swojej pogrzebowej mowie zaznaczał, że to właśnie „nieudawana skromność" Staszica „mu nawet nie pozwoliła po śmierci pozostać w grodzie, który odtąd bez błogosławieństwa wspominać imienia jego nie może” i „wyniósł nawet z niego popioły swoje do świętego ustronia, ażeby cieniom wdzięczności nie skazić ostatniej woli"21. Nie była to wprawdzie całkiem odludna lokalizacja. Bielany stanowiły bowiem cel dorocznych pielgrzymek warszawian (również tych wyżej postawionych w hierarchii spo-

15 „Kurier Warszawski”, nr 19, 22 I 1826 r., s. 77.

16 S. Staszic, Testament, [w:] W. Zawadzki, Stanisław Staszic: szkic biograficzny, Lwów 1860, s. 110.

17 Sformułowanie Fryderyka Chopina, zob. B. Szacka, Stanisław Staszic, Warszawa 1966, s. 238.

18 „Kurier Warszawski”, nr 22, 26 I 1826 r., s. 89.

19 A. Kraushar, Towarzystwo Warszawskie Przyjaciół Nauk 1800-1832: monografia historyczna osnuta na źródłach archiwalnych. Ks. 3, Czasy Królestwa Kongresowego: czterolecie przedostatnie, 1824-1828, t. 3, Kraków 1905, s. 208.

20 F. Skarbek, Mowa [...] na pogrzebie ś.p. Ministra Stanu Stanisława Staszica w kościele bielańskim miana, [w:] Zbiór mów na obchodzie pogrzebowym X. Stanisława Staszica, Warszawa 1826, s. 5.

21 A. Grzymała, Głos, [w:] Zbiór mów na obchodzie pogrzebowym, s. 29-30. 
łecznej) z okazji odpustu na Zielone Świątki ${ }^{22}$. Przez większą część roku miała tam jednak panować „cisza majestatyczna”, którą Staszic szczególnie sobie upodobał, często odpoczywając tam od pracy ${ }^{23}$. Nie bez znaczenia była również symbolika eremu jako takiego. Poprzez wybór miejsca pochówku, Staszic mógł manifestacyjnie odciąć się od „światowych" ambicji, w tym od troski o pośmiertną sławę, idąc za wzorem mnichów stosujących się do surowej reguły św. Romualda ${ }^{24}$. Reprezentant Towarzystwa Skarbek odnosił się do tej kwestii w swojej mowie, podkreślając przy tym niechęć Staszica do wyraźnego oznaczania grobu. Zmarły miał bowiem

żądać umieszczenia zwłok swoich wśród tego świętego ustronia, w ziemi, pod świeżą murawą, a nie pod głazem [tj. nagrobkiem], którego by napisy jego światowe znaczenie ogłaszały.

Wprawdzie w ten sposób Staszic mógłby potencjalnie skazywać siebie na zapomnienie, Skarbek sugerował jednak, że nie pozwoliłyby na to jego zasługi. W tym przypadku to nie grób miał upamiętniać i przyczyniać się do unieśmiertelnienia zmarłego, ale odwrotnie. Zdobyta dzięki zasługom sława Staszica miała skłaniać ku pielgrzymkom do jego mogiły, gdzie „późne syny nasze przyjdą [...] nieraz spocząć i powiedzą do dzieci swoich: Tu spoczywa przyjaciel ludzi [kursywa oryginalna - M.G.-K.]"25.

Ta „sprzeczność pozorna, jego sławy i znaczenia, z brakiem blasku i świetności powierzchownej"26 tkwiła korzeniami w społecznych przekonaniach Staszica, które zdecydowanie wyróżniały go na tle ówczesnej elity życia publicznego. Zmarły znany był bowiem z dość demokratycznego światopoglądu, w tym również awersji do arystokratycznego elitaryzmu, czego nie ukrywał od początku swojej aktywności politycznej, jeszcze w okresie sejmu wielkiego ${ }^{27}$. W pisanej w 1820 r. autobiografii ten mieszczanin z urodzenia, pochodzący z prowincjonalnej Piły, podkreślał, że

przy wstępie swoim na świat uderzyło go to nadzwyczajnie, że znalazł w owe czasy przed sobą zapory nieprzystępne w każdym stanie, w duchownym, wojskowym i w cywilnym [...] wszędzie wstydzić się musiał swego urodzenia, wszędzie je znajdował okryte wzgardą, odrzucone od czci, od urzędów i od ziemi.

Dlatego, zgodnie z jego słowami, „to stało się powodem, że zaczął zastanawiać się, szukać przyczyny źródłowej tego pokrzywdzenia i zboczenia towarzystw ludzkich z dro-

22 K.W. Wójcicki, Cmentarz Powązkowski pod Warszawą, t. 3, Warszawa 1858, s. 211-213.

23 „Siedzieliśmy właśnie w ulubionym miejscu wielkiego męża pod starym dębem. Tu w wolnych chwilach od zatrudnień urzędowych, w dni pogodne na wiosnę, przez lato do późnej jesieni, Stanisław Staszic w tej samotnej ustroni spoczywał, czytając książki i kreśląc w nich ołówkiem notatki. W dnie powszednie panowała tu cisza majestatyczna. Miał Staszic stąd widok piękny i otwarty na Wisłę i dalekie jej okolice; słuchał szumu tych starych sosen i starszych dębów, do którego z rana i nad wieczorem łączył się głos dzwonu z klasztoru Kamedułów. Ukochał on to miejsce i polecił w testamencie, ażeby zwłoki jego pochowane zostały przy tutejszym kościele”, cyt. za K.W. Wójcicki, Typowe postacie i okolice dawnej Warszawy, „Biblioteka Warszawska” t. 4, 1876 , s. 348.

24 E. Jabłońska-Deptuła, Przystosowanie i opór. Zakony męskie w Królestwie Kongresowym, Warszawa 1983, s. 316.

25 F. Skarbek, op. cit., s. 5.

26 W. Szweykowski, Kazanie, [w:] Zbiór mów na obchodzie pogrzebowym, s. 7.

27 A. Grześkowiak-Krwawicz, O formę rządu czy o rząd dusz? Publicystyka polityczna Sejmu Czteroletniego, Warszawa 2000 , s. $145-149$. 
gi ich ogólnego szczęścia", utożsamianego przez niego ze społeczną demokratyzacją ${ }^{28}$. Kajetan Koźmian, współpracownik Staszica z Rady Stanu i zarazem członek Towarzystwa, charakteryzował prezesa jako „głównego nieprzyjaciela wszelkiej arystokracji”29. Koźmian miał na myśli nie tyle warstwę społeczną, ile określony sposób myślenia o społeczeństwie w kategoriach hierarchicznych, przejawiający się w alienacji elity, również na poziomie powierzchowności. Zauważmy, że pomimo najwyższych godności, do których Staszic doszedł w rządzonym przez zamożną szlachtę Księstwie Warszawskim i Królestwie Polskim, nigdy nie czynił on starań o nobilitację (która w Królestwie była możliwa) dla siebie bądź swoich najbliższych. Stronił również od atrybutów elitarnego statusu (takich jak np. rezydencje czy reprezentacyjne portrety), choć były one w zasięgu jego całkiem sporych możliwości finansowych ${ }^{30}$.

Co ważne z punktu widzenia badań nad pośmiertnym upamiętnieniem Staszica, charakteryzująca go za życia wyraźna niechęć do blichtru i wywyższania się była również istotnym wątkiem pogrzebowego dyskursu. Skarbek podkreślał w swojej mowie, że

majątek, najwyższe dostojeństwa w kraju, znamiona zasługi publicznej [takie jak $\mathrm{np}$. ordery], wszystkiego dostąpił Staszic w ciągu czynnego życia swego, lecz się nigdy dumą nad innych nie wynosił, niczym się z pozoru od pospolitego człowieka nie różnił.

Reprezentant Towarzystwa dodawał przy tym, że „mocno przejęty tą prawdą, że wartość człowieka w cnocie, nie w powierzchownym zaszczycie, [Staszic] nie jaśniał nigdy zewnętrznym blaskiem, jaśniał zawsze wielkimi duszy przymiotami"31. Do tematu skromności odniósł się też wówczas Grzymała:

widział Staszic, że nic tak nie rozrywa węzła towarzyskiego jak sama powierzchowność [...], która ustawicznie przybierając na siebie nieomylności znamiona, szuka tłumów, ażeby mogła na nich wywierać całą rozmaitość wrażeń podziwienia. Wiedział on, że na tym świecie trzeba cicho postępować, bo kto ludzi budzić zamierza, tego wkrótce otoczy zazdrość, a z nią nie masz przymierza

między ludźmi ${ }^{32}$. Zapewne obecny na pogrzebie student prawa Jan Nepomucen Leszczyński pisał natomiast w okolicznościowym wierszu:

Wśród nauk, wśród dostojeństw, nie pragnął uczczenia, Godzien czci nieśmiertelnej - unikał jej cienia.

Wśród bogactw wzgardził dumą, dumnymi honory,

Bo to nie człowiek - raczej człowieka pozory.

W prostocie zawsze wielki - a w wielkości skromny33.

28 S. Staszic, Krótki rys życia mego, [w:] S. Staszic, Pisma filozoficzne i społeczne, t. 1, oprac. B. Suchodolski, Warszawa 1954, s. 5.

29 K. Koźmian, Pamiętniki, t. 2, Wrocław 1972, s. 192.

30 Zob. J. Jedlicki, Szlachta, [w:] Przemiany społeczne w Królestwie Polskim 1815-1864, red. W. Kula, J. Leskiewiczowa, Wrocław 1979, s. 37

31 F. Skarbek, op. cit., s. 3-4.

32 A. Grzymała, op. cit., s. 27-28.

33 J.N. Leszczyński, Elegija na zgon JW. Stanisław Staszica, ministra stanu prezesa Towarzystwa Przyjaciół Nauk, Warszawa 1826 , s. 8. 
Wprawdzie zgodnie z ustaleniami Adriana Wesołowskiego, kluczowym czynnikiem pośmiertnej sławy i uwielbienia Staszica była nie tyle jego skromność, ile szeroko zakrojona działalność dobroczynna ${ }^{34}$. To właśnie $w$ ten sposób pożytkował on nagromadzone przez lata dobra, co zresztą było szczególnie podkreślane w dyskursie pogrzebowym, w tym również przez Skarbka. Towarzystwo Przyjaciół Nauk było wszakże głównym beneficjentem niezrównanej hojności zmarłego prezesa, zawdzięczając mu zarówno swoją siedzibę, jak i przeznaczony dla jej ozdoby pomnik Mikołaja Kopernika. Warto w tym miejscu dodać, że Wesołowski nie różnicował zebranych przez siebie wypowiedzi o filantropii Staszica pod względem specyfiki nadawców i charakterystycznych dla nich treści (zresztą bardziej interesował go szeroki - międzynarodowy - kulturowy kontekst kultu Staszica, niż lokalne uwarunkowania, interesy i ambicje). Nie zauważył więc, że „przyjaciele nauk” przede wszystkim podkreślali wagę tych przejawów dobroczynności Staszica, które dotyczyły samego Towarzystwa (chociażby poprzez wymienianie ich na pierwszym miejscu). Poprzez ich zestawianie z pomocą dla chłopów, ubogich, sierot i kalek (jak czynił to Skarbek), a innym razem deklarowanie, że oprócz TKWPN „kraj cały” był jego dłużnikiem (jak ujął to Julian Ursyn Niemcewicz w nieco późniejszej laudacji35), „przyjaciele nauk” mogli podkreślić szczególną społeczną wartość swojej instytucji, działającej z myślą o dobru powszechnym, a nie jakimkolwiek partykularnym ${ }^{36}$. Pamiętajmy, że Towarzystwo od początku funkcjonowało przede wszystkim dzięki hojności członków i sympatyków, Staszic był więc znakomitym przykładem jak najbardziej pożądanej (z punktu widzenia interesów TKWPN) postawy.

Uznanie filantropii za główny czynnik sławy Staszica samo w sobie niewiele jednak mówi o przyczynach odrzucenia „pomysłów” Tatarkiewicza. Jak się bowiem przekonamy w dalszej części tego artykułu, niechęć do nawet możliwie oszczędnej, ale jednak konwencjonalnej artystycznej formy, której przykładem były projekty rzymskiego stypendysty, nie oznaczało wcale rezygnacji Towarzystwa z jakiegokolwiek (tym bardziej bezkosztowego) upamiętnienia, i to w monumentalnej skali. W tym przypadku kult prezesa-filantropa należy bowiem rozpatrywać w kontekście omówionego powyżej odrzucania przez niego tradycyjnych oznak społecznego statusu. Skarbek wspominał podczas pogrzebu, że

liczyła już ludzkość wielu takich dobroczyńców, którzy przepędziwszy życie w swobodnym dostatków używaniu, wielkie majątki wsparciu cierpiących lub dobru pospolitemu poświęcili, lecz mało nader w dziejach świata znajdziesz przykładów takich, którzy by z uszczerbkiem własnych potrzeb i przyjemności pożycia na to tylko gromadzili majątek, aby go potem, jako źródło dobra pospolitego na kraj własny wylać, gdy już wszelka pochwała i głos wdzięczności narodu obcymi dla nich będą ${ }^{37}$.

Wielkość Staszica miała więc polegać nie tylko na dobroczynności, lecz również na nietypowej dla dawniejszych filantropów skromności, zresztą samej w sobie będącej kluczowym

34 A. Wesołowski, Nieśmiertelny i dobroczynny. Historyczne badanie genezy i charakteru sławy Stanisława Staszica, „Kwartalnik Historyczny” t. 125, 2018, nr 1, s. 29-63.

35 J.U. Niemcewicz, Obraz życia i czynów Stanisława Staszica, „Roczniki Towarzystwa Warszawskiego Przyjaciół Nauk" t. 20, 1828, s. 43.

36 W podobny sposób Towarzystwo prezentowało ideę budowy pomnika Kopernika, zob. M. Getka-Kenig, Pomniki publiczne i dyskurs zasługi w dobie „wskrzeszonej” Polski lat 1807-1830, Kraków 2017, s. 254.

37 F. Skarbek, op. cit., s. 4-5. 
źródłem jego tak dobrze wykorzystanego majątku. Pogrzebowy dyskurs promował na przykładzie Staszica ideał człowieka bogacącego się nie dla siebie, lecz dla społeczeństwa ${ }^{38}$.

Zauważmy, że twórczość artystyczna na ziemiach polskich miała na przełomie XVIII i XIX w. dość silne konotacje elitarne, wynikające z tradycyjnej dominacji mecenatu najbogatszych (monarchy, magnatów, Kościoła), której dopiero w okresie Królestwa zaczynała przeciwdziałać powolna demokratyzacja dostępu do tej dziedziny kultury (np. poprzez wystawy publiczne, organizowane w Warszawie od 1819 r.) ${ }^{39}$. „Aż nadto wymawiano kraśnym sztukom” i ich „mistrzom, że majętnym tylko i zbytkowi służyli”, utyskiwał już w 1791 r. architekt Chrystian Piotr Aigner, przyszły członek TKWPN ${ }^{40}$. Jednak nawet w łonie Towarzystwa, jego pierwszy prezes Jan Chrzciciel Albertrandi dostrzegał w "sztukach wyzwolonych i umiejętnościach wyborniejszych” jedynie „najmilszą zabawę [...] ludzi spokojność kochających", czyli tych nielicznych, którzy w ówczesnych warunkach społecznych mogli sobie na luksus takiej „spokojności” pozwolić ${ }^{41}$. Niby starał się przeciwdziałać takiemu poglądowi Stanisław Kostka Potocki, kiedy w Winkelmanie polskim (jedynej obszerniejszej rozprawie na temat sztuki, jaka powstała w kręgu TKWPN) polemizował z tezą Jeana Jacquesa Rousseau o potrzebie „zwrotu do pierwiastkowej świata prostoty"42. Mając zamiar udowodnić, że jego pionierska publikacja w języku polskim nie „zwraca od rzeczy użytecznych [...] niebezpieczną płochej ciekawości ponętą"43, wysuwał jednak argumenty, które nie mogły być zbytnio przekonujące. Pisząc o roli sztuki jako lekarstwa na „najokropniejszą z chorób, na tę mówię sytość wszystkiego, którą właśnie nudzi szczęście" lub podkreślając, że zainteresowanie sztuką (czy wręcz kolekcjonerstwo) łączy się integralnie z „duchem filozoficznej niepodległości, co gardząc pozorami potęgi i wielkości, w swobodzie domowego życia umie znaleźć szczęście prawdziwie"44, Potocki zdradzał arystokratyczne ograniczenia swoich horyzontów intelektualnych.

W tym kontekście nie dziwi, że sam Staszic niezbyt interesował się sztuką, nie mówiąc już o inwestowaniu swojego czasu i pieniędzy w jej rozwój. Co więcej, jako działacz oświatowy chciał ograniczyć publiczną edukację artystyczną do lekcji rysunku, potrzebnego na kierunkach technicznych, a uznawanych przez niego za najbardziej przydatne ze społecznego punktu widzenia. Jako zastępca ministra edukacji w Królestwie znamiennie różnił się w tym temacie ze swoim przełożonym, czyli Potockim (fakt, że pozytywnie wypowiadał się o jego artystycznych zainteresowaniach w pośmiertnej „pochwale” nie świadczy wcale o tym, że zmienił zdanie - w tym tekście bardziej zresztą doceniał studia Potockiego nad językiem i literaturą polską) ${ }^{45}$. W życiowym dorobku Staszica znajduje-

$38 \mathrm{Na}$ ten temat zob. A. Wesołowski, op. cit., s. 38 (autor nie rozwija jednak tej kwestii w swojej rozprawie).

39 S. Kozakiewicz, Malarstwo warszawskie na tle przemian gospodarczych, społecznych i politycznych w Królestwie Polskim (1815-1830), „Biuletyn Historii Sztuki”, t. 14, 1952, nr 2, s. 40-41; M. Getka-Kenig, Wystawy sztuk pięknych w Warszawie jako narzędzie polityki artystycznej władz Królestwa Polskiego w latach 18151830, „Folia Historiae Artium” t. 16, 2018, s. 63-78.

40 P. Aigner, Budownictwo wiejskie z cegły glino-suszonej z plantami chałup wiejskich stosowne do gospodarstwa narodowego, Warszawa 1791, s. [3].

41 J. Albertrandi, O muzach, „Roczniki Towarzystwa Warszawskiego Przyjaciół Nauk” t. 1, 1802, s. 183.

42 S.K. Potocki, O sztuce u dawnych, czyli Winkelman polski, t. 1, Warszawa 1815, s. 2.

43 Ibid., s. 1.

44 Ibid., s. 9.

45 Zob. K. Bartnicka, Polskie szkolnictwo artystyczne na przełomie XVIII i XIX w.: 1764-1831, Wrocław 1971, s. 167; S. Staszic, Pochwała Stanisława Potockiego, „Roczniki Towarzystwa Królewskiego Warszawskiego Przyjaciół Nauk" t. 18, 1825, s. 105-106. 
my wprawdzie dwa artystyczne przedsięwzięcia, którym osobiście patronował, a nawet współfundował, czyli wspomniany „wspaniały przybytek"46 dla TKWPN oraz pomnik Kopernika (zdecydował również o wyborze jego twórcy, czyli słynnego już wówczas Thorvaldsena). Były to jednak przykłady inwestowania w prestiż nauki, która nie cieszyła się wówczas tak wielkim poważaniem w polskim społeczeństwie, jak np. zasługi militarne (o czym świadczyła potrzeba znacznego wsparcia dla prac nad monumentem Kopernika, nie dających się w pełni sfinansować z prowadzonej przez lata ogólnonarodowej składki ${ }^{47}$ ). Staszic odegrał też pewną rolę przy budowie nowego pomnika Unii Lubelskiej w Lublinie (z inicjatywy Towarzystwa) oraz pomnika Szosy Brzeskiej (inicjatywa wyszła od Komisji Rządowej Spraw Wewnętrznych, w której władzach zasiadał) ${ }^{48}$. Były to jednak przedsięwzięcia czysto polityczne, wykorzystujące formę artystyczną jako narzędzie wzmacniające (przykuwające uwagę) ideologiczny przekaz. W tym kontekście Staszic może być postrzegany bardziej jako mecenas reprezentowanych przez te inwestycje idei niż sztuk pięknych samych w sobie.

Pielęgnowanie autorytetu takiej instytucji jak Towarzystwo za pomocą elitarnych środków wyrazu było czymś zupełnie innym niż upamiętnianie stojącej na jej czele jednostki, do tego głównego dobroczyńcy. Miało to tym większe znaczenie, że działania TKWPN również odznaczały się wyraźnie demokratycznym rysem (wszyscy członkowie, niezależnie od pozycji społecznej, tytułowali się „kolegami”), „przykładając się do rozszerzenia nauk i umiejętności w polskim języku"49. Abstrahując od możliwych moralnych oporów „przyjaciół nauk” wobec sprzeniewierzania się ostatniej woli prezesa, trzeba przyznać, że Towarzystwo nie miało żadnego interesu w tym, aby wznosić mu monumentalny grobowiec. Jak wspomniałem, opierało ono swój prestiż również na osobistej sławie prezesa-skromnego filantropa, a tę można było przecież skompromitować pretensjonalnymi hołdami sepulkralnymi. Można domniemywać, że „przyjaciele nauk” nie chcieli kreować publicznego wizerunku swojego prezesa jako bardziej „przyjaciela ludu" niż "ludzi" - kogoś podchodzącego do aktów dobroczynności w typowo paternalistyczny sposób, wynikający z poczucia wyższości, co mogłaby wyrażać wytworna forma pomnika, stwarzająca naturalny dystans pomiędzy pamiętanym i pamiętającymi. Stereotypowym przykładem takiego unieśmiertelnionego w kamieniu arystokratycznego „przyjaciela” gminu był Małachowski. Jego monument dłuta Laboureura - z polską inskrypcją „przyjacielowi ludu”, dopełniającą właściwy łaciński napis informujący o zasługach zmarłego - uwzględniał potężny, siedzący posąg marszałka, ustawiony na równie potężnym sarkofagu i górujący nad oglądającymi, tym samym utrzymujący z nimi wyraźnie hierarchiczną relację (Ryc. 4) ${ }^{50}$.

46 Cyt. za F. Skarbek, op. cit., s. 4.

47 Zob. H. Kotkowska-Bareja, Pomnik Kopernika, Warszawa 1973, s. 47.

48 Staszic brał udział w uroczystości złożenia kamienia węgielnego pod pomnik Szosy Brzeskiej: „Gazeta Warszawska", nr 98, 20 VI 1825, s. 1346; na temat udziału Towarzystwa w budowie Pomnika Unii Lubelskiej zob. H. Gawarecki, O dawnym Lublinie: szkice z przeszłości miasta, Lublin 1974, s. 299-302.

49 Ustawy Towarzystwa Królewskiego Warszawskiego Przyjaciół Nauk, Warszawa 1814, art. 1, s. 3; J. Michalski, op. cit., s. 74; M. Janowski, Narodziny inteligencji 1750-1831, Warszawa 2008, s. 164.

50 M. Getka-Kenig, Pomniki publiczne, s. 292-297. 
Jak wspomniałem, Towarzystwo nie zamierzało wcale pozostawić miejsca pochówku swojego prezesa i powszechnie szanowanej osoby publicznej bez jakiejkolwiek formy upamiętnienia. Wszakże podczas pogrzebu zastrzegało jedynie, że nie będzie to grobowiec głoszący jego „światowe znaczenie”51 . „Przyjaciele nauk” rozumieli jednak ten warunek inaczej niż Tatarkiewicz. Nie szukali bowiem odpowiednich środków wyrazu w ramach kanonu sztuki sepulkralnej, ale przejawiali postawę wręcz antyartystyczną (z ówczesnego punktu widzenia). Już dwa dnia po zgonie prezesa, a dwa dni przed jego pogrzebem, na posiedzeniu ogólnym Towarzystwa podjęto uchwałę o postawieniu „kamienia granitowego na grobie prezesa Staszica”52. Miał to być „prosty, znacznej wielkości kamień, którego sprowadzeniem i ustawieniem na miejscu podjął się zająć" Ludwik Metzell (Metzel, Mecel) ${ }^{53}$. Był on inżynierem rządowym, budowniczym dróg i mostów, projektantem słynnego parku Zofiówka na Ukrainie, uchodzącym za zapatrzonego w nauki czysto praktyczne i pogardzającego wszystkimi „niematymatykami” i „nieinżynierami”"54. Nie był on jeszcze wówczas członkiem Towarzystwa (stał się nim w 1827 r.), lecz po prostu „czcicielem zasług Staszica”"55.

Ze względu na okres zimowy uskutecznienie tego pomysłu zostało jednak odłożone do lata tego roku. Wiadomo, że Metzell dokonał w międzyczasie wyboru jakiegoś głazu, mającego znajdować się „na polu wsi Parysowa” ${ }^{56}$ (teren na pograniczu dzisiejszych stołecznych dzielnic Żoliborz i Bielany, w pobliżu ulicy Powązkowskiej ${ }^{57}$ ) bądź, zgodnie z innym źródłem, „za Młocinami”58. Znał on dobrze tę okolicę, gdyż w 1818 r. zaprojektował drogę bitą pomiędzy Warszawą a Bielanami59. W opinii Skarbka i geologa Marka Antoniego Pawłowicza wskazany kamień był jednak „za wielki"60. Nie zachowały się jednak żadne dane dotyczące jego rozmiarów, ani preferencji krytyków w tym względzie, nie wiadomo też, na czym polegał problem ze zbytnią wielkością (być może chodziło o kwestie transportowe). Sprawa została poruszona w memorandum Kazimierza Brodzińskiego, który w imieniu wydziału nauk Towarzystwa składał w czerwcu 1826 r. wniosek, aby wybór nowego kamienia powierzono specjalnej deputacji, w której składzie znaleźliby się dwaj lub trzej członkowie Towarzystwa, jak również Metzell. Deputacja miałaby również sprawować nadzór nad wydzielonym funduszem na ten cel oraz „zająć się wszystkim tak, aby pomnik w tym roku był ustawiony"61.

Co jednak najważniejsze, wydział nauk ustami Brodzińskiego doceniał sam pomysł upamiętnienia „miłośnika natury” za pomocą polnego głazu. Nie uważał jednak za stosowne, aby stanął on na jego grobie ze względów symbolicznych (sam Metzell nie propo-

AGAD, sygn. 64, Protokół posiedzeń działu nauk Towarzystwa z 17 V 1826 r., s. 166.

53 AGAD, sygn. 45, Wniosek na sesję centralną Towarzystwa z 4 VI 1826 r., s. 29 (przedruk tego dokumentu w: A. Kraushar, op. cit., s. 250-251).

54 Zob. M. Gajewski, Metzell (Mecel) Ludwik Chrystian h. Trójgwiazd (1769-1848), [w:] Polski Słownik Biograficzny, t. 20, Wrocław 1975, s. 473-474.

55 AGAD, Wniosek na sesję centralną Towarzystwa, s. 29.

56 Cyt. za A. Kraushar, op. cit., s. 225.

57 M. Gajewski, Urządzenia komunalne Warszawy: zarys historyczny, Warszawa 1979, s. 410.

58 AGAD, Wniosek na sesję centralną Towarzystwa, s. 30.

59 K.W. Wójcicki, Cmentarz Powązkowski, s. 213.

60 AGAD, Wniosek na sesję centralną Towarzystwa, s. 30.

61 Ibid. 
nował, aby położyć go bezpośrednio na mogile, ale „w miejscu najbliższym, przez ś.p. prezesa ulubionym”). Brodziński stwierdził bowiem, że „prosty wielki kamień nie może być nagrobkiem", gdyż "sprzeczny by był zwykłemu na nagrobkach napisowi: «sit illi terra levis»". Przedstawił również drugi argument przeciwny temu pomysłowi, a wynikający ze specyfiki miejsca, w którym pochowano Staszica, czyli pod zewnętrzną ścianą kościoła:

umieszczony pod kościołem chociażby największy kamień, nie odbijałby [się] przy masie muru, a tak w miejscu tym, wcale by nie odpowiadał symbolicznemu znaczeniu do którego jest przeznaczony.

Te dwie przyczyny podważały w jego opinii słuszność takiej formy oznaczania miejsca pochówku. Nie godziły one jednak w sam pomysł upamiętnienia Staszica za pomocą granitowego głazu, który mógłby stanąć w innym miejscu. Brodziński zauważał bowiem, że:

wypada [...] aby ten kamień nie był nagrobkiem, ale pomnikiem, zatem nie na zwłokach zmarłego, ale umieszczonym być powinien w miejscu lub przez ś.p. Staszica ulubionym, lub w położeniu wydatnym, dostępnym, gdzieby jako prosty kamień przyzwoicie daleko od budynków oznaczał pomnik wśród natury miłośnikowi natury poświęcony. Miejsce takie zostawić należy wyborowi Deputacji. Najlepsze jednak by było na wzgórku nad zdrojem dojeżdżając brzegiem Wisły do Bielan, gdzie osadzony na miejscu nieco okopanym od strony muru drzewami ocieniony piękny dawałby widok.

Nowa lokalizacja dla kamienia Metzlla, którą zaproponował Brodziński, „daleko od budynków [...] wśród natury", wyrażała tę samą ideę odcięcia się od świata co sama koncepcja grobu na terenie kamedulskiego eremu. Musiało to być oczywiście miejsce „dostępne", gdyż w przeciwnym razie zachodziłaby tutaj sprzeczność z samą ideą pomnika. Był to jednak wciąż dość nietypowy pomysł, gdyż przyciąganie powszechnej uwagi stanowiło istotę tego typu przedsięwzięć, czego przykładem ówczesne starania o jak najbardziej wyeksponowaną lokalizację dla warszawskiego monumentu księcia Józefa Poniatowskiego ${ }^{62}$. Wydział nauk chciał więc postawić Staszicowi pomnik stanowiący sam w sobie akt gloryfikacji, ale taki, który osadzałby jego kult w naturalnym kontekście i nie kompromitował jego demokratycznych przekonań.

Możemy domniemywać, że propozycja Metzlla była inspirowana geologicznymi zainteresowaniami zmarłego zarówno w jego pracy naukowej (jako autora np. O ziemiorództwie Karpatów), jak i urzędniczej (jako inicjatora szkoły górniczej w Kielcach) ${ }^{63}$. Warto jednak zaznaczyć, że wykorzystanie nieociosanego głazu w celach komemoracyjnych było już wcześniej (choć sporadycznie) stosowane wobec osób, które nie miały nic wspólnego z tą dziedziną nauki. Za przykład z terenu dawnej Rzeczypospolitej może służyć kamień z napisem „AMICITIAE ET VIRTUTI/ MEMORIA ET GRATITUDO/ ANNO 1798”, który Michał Jan Borch umieścił w parku pałacowym w Warklanach (ob. Łotwa) i poświęcił pamięci jego

62 H. Mościcki, Pozgonna cześć dla księcia Józefa (pogrzeb - pomniki - pieśń i legenda), Warszawa [1922], s. $102-104$.

63 Zob. na ten temat np.: K. Jakubowski, Stanisław Staszic jako geolog: refleksje rocznicowe, „Kwartalnik Historii Nauki i Techniki" t. 22, 1977, nr 2, s. 333-340; Stanisław Staszic i jego dzieło, red. J. Topolski, Poznań 1978 (tam kilka artykułów poświęconych różnym aspektom geologicznych zainteresowań Staszica). 
projektanta, Vincenza de Mazottiego ${ }^{64}$. W tym przypadku głaz odnosił się do dzieła upamiętnionego, czyli „naturalnego”, krajobrazowego założenia rezydencjonalnego, ale był on równocześnie wyrazem prywatnego charakteru tego aktu komemoracji, odnoszącego się do przyjacielskiej, a więc również „naturalnej” (czyli pozbawionej oficjalnej sztuczności) relacji międzyludzkiej. Metaforyczne skojarzenie nieociosanego kamienia ze sferą prywatną, a nie publiczną, mogło czynić z niego odpowiednie narzędzie upamiętnienia również w przypadku Staszica. Sam pochówek na Bielanach był wszakże interpretowany w kategoriach ucieczki przed „światem”, a zatem również typowymi dla niego elitarnymi aktami pośmiertnej gloryfikacji poprzez artystycznie opracowane nagrobki. Nieociosany głaz (z wyrytym nazwiskiem upamiętnianego) stanowił również zwieńczenie monumentalnego kopca ku czci Kościuszki, który na początku lat dwudziestych XIX w. usypano w Krakowie. Stanowił on uzupełnienie samego kopca, traktowanego nie tylko jako odwieczna na tym terenie forma upamiętniania wielkich, ale również taka, która najlepiej przemawiałaby do chłopskich czcicieli Kościuszki, nieczułych na wytworny artyzm tradycyjnych pomników ${ }^{65}$.

Opisany powyżej pomysł Metzlla, zmodyfikowany później przez wydział nauk, nie został jednak zrealizowany. Być może również w tym przypadku zadecydowały względy finansowe. Fakt, że aż do 1830 r. Towarzystwo absorbowała ciągnąca się latami, a priorytetowa dla samego Staszica sprawa budowy pomnika Kopernika, może tutaj wiele wyjaśniać. Warto dodać, że początkowa wersja inskrypcji na cokole monumentu ku czci wielkiego astronoma miała wspominać o Staszicu jako patronie tego przedsięwzięcia („,cura et studio Stanislai Staszic, Consilii Status, Equitis Torquati Aquilae Albae et Sancti Stanislai"), później jednak zarzucono ten pomysł, być może właśnie przez wzgląd na jego przysłowiową skromność66. Zanim Towarzystwo przestało istnieć po powstaniu listopadowym, udało mu się jednak umieścić w miejscu pochówku Staszica „zwyczajny nagrobek”, zgodnie zresztą z propozycją Brodzińskiego. Miał on powstać „z osobnych składek lub z innego funduszu, względem czego" należało „znieść się z WW. egzekutorami testamentu ś.p. prezesa"67. W efekcie powstała prosta, prostokątna płyta, z inskrypcją uwzględniającą jedynie imię, nazwisko oraz daty życia, bez "napisów”, które by - jak to ujął Skarbek w mowie pogrzebowej - „jego światowe znaczenie ogłaszały" (Ryc. 5). Tablica zachowała się do dziś, choć obecna aranżacja grobu z dodatkowym popiersiem zmarłego (z insygniami Orderu Orła Białego) oraz krzyżem pochodzi z późniejszego okresu. Ten dość oficjalny wizerunek, nie mający wiele wspólnego z oryginalną ideą grobu Staszica, został ustawiony z inicjatywy nieznanego „wielbiciela" jego „zasług” w 1856 r., z okazji trzydziestej rocznicy śmierci. Rzeźbę miano odlać w hucie białogońskiej, założonej z inicjatywy zmarłego. Za wzorzec miała posłużyć plakieta z płaskorzeźbionym portretem Staszica autorstwa Williama Kimensa ${ }^{68}$.

64 J. Polanowska, Ogród w Warklanach - dzieło właściciela Michała Jana Borcha i architekta Vincenza de Mazottiego, „Biuletyn Historii Sztuki” t. 74, 2012, nr 3/4, s. 566.

65 Pamiętajmy jednak, że równocześnie ten porfirowy monolit miał też symbolizować narodową jedność. Zob. M. Getka-Kenig, Pomniki publiczne, s. 337-340.

66 Projekt napisu autorstwa Krzysztofa Wiesiołowskiego, zob. AGAD, sygn. 56, s. 49. Zob. na ten temat: M. GetkaKenig, Pomniki publiczne, s. 250.

67 AGAD, Wniosek na sesję centralną Towarzystwa, s. 31.

68 H. Łopaciński, Grób Staszyca na Bielanach pod Warszawą (z powodu 80-tej rocznicy śmierci), „Nasz Kraj” t. 2, 1906, nr 5, s. 29. W 1876 r., przy okazji kolejnej okrągłej rocznicy śmierci, Towarzystwo Hrubieszowskie rozbudowało bielański grób. Dodano wówczas nową podstawę pod starą płytę oraz kamienny krzyż z postumentem („rodzaj kapliczki”), w którego niszy ustawiono wspomniane popiersie. Miejsce pochówku Staszica przetrwało w tym kształcie do dziśs. 
Ten charakterystyczny, późniejszy brak zrozumienia dla oryginalnej koncepcji jak najskromniejszej mogiły nie był wówczas odosobniony. Podzielali go bowiem również dawni członkowie Towarzystwa i bliscy zmarłego, tacy jak Koźmian. Pisał on w połowie stulecia, że wprawdzie Staszic „rozkazawszy się pochować na Bielanach zalecił grób swój okryć prostym głazem”, w jego przekonaniu „obdarzony przez niego kraj tego, który własnym kosztem Kopernikowi wzniósł posąg” powinien „uczcić jakimś grobowcem lub pomnikiem godnym jego i narodu”. Dlatego też po upływie „dwudziestu kilku lat” Koźmian miał dopisać do posiadanego przez siebie portretu „mistrza i przyjaciela” krytyczny wobec narodu dwuwiersz:

\section{Z jego daru Kopernik w spiżu ziomkom ożył,} jemu na pomnik ziomek i głazu nie złożył69.

Sposób patrzenia Koźmiana, jak i wspomnianego anonimowego „wielbiciela zasług” na kwestię nagrobka Staszica mógł wynikać z upływu czasu, kiedy dokonania Staszica (zwłaszcza te dotyczące gospodarczego i naukowego rozwoju, a mniej dobroczynności) nie tylko nie traciły na znaczeniu, lecz wręcz na nim zyskiwały. Pamiętajmy również, że w tym czasie nie istniało już TKWPN, zlikwidowane tuż po powstaniu listopadowym. Swoją rolę musiała też odegrać wyraźna ewolucja kontekstu społeczno-kulturowego, w tym przede wszystkim zmiana stosunku do aktów upamiętniania. Zdążyła już okrzepnąć nowoczesna koncepcja upamiętnienia publicznego, które zamiast dzielić społeczeństwo na lepszych i gorszych, miało jednoczyć i stanowić punkt odniesienia dla demokratyzującej się tożsamości zbiorowej. Pomniki wybitnych jednostek nie miały bowiem ich ubóstwiać, lecz wyznaczać powszechny wzór do naśladowania. Była to wprawdzie ta sama idea, która przyświecała Staszicowi i Towarzystwu przy wznoszeniu pomnika Kopernika. Jednak ten nowoczesny, demokratyczny sposób myślenia o artystycznej komemoracji pozostawał wówczas dopiero na wstępnym etapie rozwoju na ziemiach polskich ${ }^{70}$. Wraz z postępującą na przestrzeni pierwszej połowy XIX w. demokratyzacją rzeczywistości społecznej, obejmującą upowszechnienie dostępu do sztuki i wiedzy o niej, jak również minimalizację znaczenia elitarnego mecenatu na rzecz patronatu instytucjonalnego oraz obrotu rynkowego, sztuki piękne powoli zdejmowały z siebie odium arystokratyczności. W ten sposób nawet najwięksi demokraci i krytycy feudalnych relacji społecznych mogli stawać się przedmiotem dość konserwatywnych (pod względem formy) komemoracyjnych zabiegów, bez cienia kontrowersji. Równocześnie, ta konserwatywna forma sama w sobie mogła ulegać przemianom, dostosowując się do nowych realiów społecznych, jak i specyfiki osoby upamiętnianej. Dobrym tego przykładem był pierwszy, niepowiązany z grobem, pomnik Staszica, który w 1906 r. odsłonięto w Kielcach ${ }^{71}$. Popiersie dawnego prezesa TKWPN (upamiętnionego w tym mieście ze względu na swoją działalność rządową, a ściślej inicjatywę założenia szkoły górniczej), zostało w tym przypadku ustawione na postumencie będącym równocześnie wielką, półkolistą („grecką") ławką (Ryc. 6). Ten typowy dla przełomu XIX i XX w. sposób komemoracji publicznej, charakterystyczny zwłaszcza dla przestrzeni parkowych (również w kieleckim przypadku), może być 
interpretowany jako wyraz dążenia do ograniczania dystansu pomiędzy pamiętanym, a pamiętającym, w imię demokratycznych ideałów epoki ${ }^{72}$.

Podsumowując, przypadek pomnika nagrobnego Staszica stanowi znamienny epizod z dziejów Towarzystwa Królewskiego Warszawskiego Przyjaciół Nauk, gdyż wiele mówiący o jego strategii wizerunkowej w okresie Królestwa Polskiego. Towarzystwo interesowało się sposobem upamiętnienia swojego prezesa i dobroczyńcy, brało jednak pod uwagę fakt, że Staszic reprezentował nowy typ bohatera, którego publiczny kult wymagał innowacyjnych form upamiętnienia. Istotnym czynnikiem jego pośmiertnej popularności była nie tylko sama działalność dobroczynna, ale również zewnętrzna skromność i demokratyczne przekonania, wyróżniające Staszica na tle ówczesnej elity społeczno-politycznej. Wydaje się, że to właśnie było powodem odrzucenia zaproponowanych Towarzystwu projektów nagrobka autorstwa Tatarkiewicza na rzecz "naturalnego” głazu, który był zaprzeczeniem ówczesnego kanonu ekspresji artystycznej, jednoznacznie kojarzonego zresztą z obcym Staszicowi elitaryzmem. W ten sposób Towarzystwo nie tylko czyniło zadość życzeniom zmarłego, lecz również mogło podkreślić wyjątkowość Staszica jako prawdziwego demokraty, który dokonywał aktów dobroczynności nie dla osobistego prestiżu, lecz społecznego dobra. Jako że przejawem tego ostatniego miała być właśnie działalność Towarzystwa, tak hojnie wspierana przez Staszica, „przyjaciele nauk” mieli ewidentny interes w tym, aby nie podważać mitu skromnego filantropa - wszakże czystość jego intencji nobilitowała tę instytucję. Gdyby ten drugi monument powstał, stanowiłby istotny wkład Towarzystwa w rozwój nowoczesnego myślenia o komemoracji na ziemiach polskich.

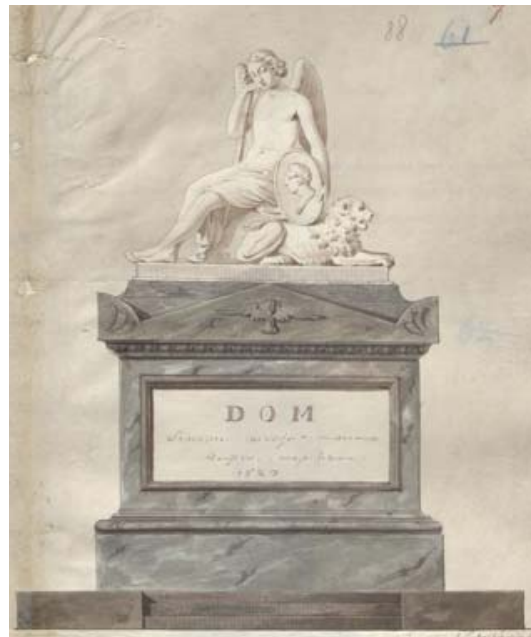

Ryc. 1. J. Tatarkiewicz, Projekt nagrobka Stanisława Staszica - wariant pierwszy (źródło: AGAD, zesp. Towarzystwo Królewskie Warszawskie Przyjaciół Nauk, sygn. 56 , s. 88 ).

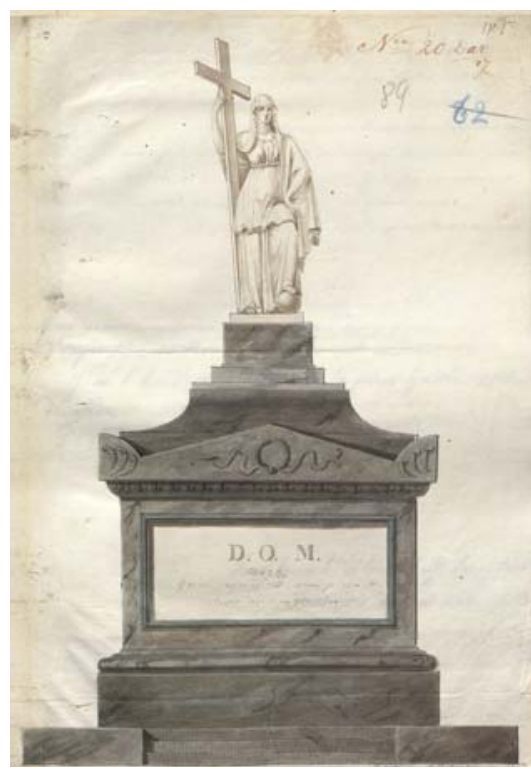

Ryc. 2. J. Tatarkiewicz, Projekt nagrobka Stanisława Staszica - wariant drugi (źródło: AGAD, zesp. Towarzystwo Królewskie Warszawskie Przyjaciół Nauk, sygn. 56 , s. 89 ).

72 Na temat ideowych motywacji tego typu pomników-ławek (na przykładzie Stanów Zjednoczonych) zob. M. Barnett Deusner, The Impossible Exedra. Engineering Contemplation and Convivality in Turn-of-the-Century America, [w:] Housing the New Romans. Architectural Reception and Classical Style in the Modern World, red. K. von Stackelberg, E. Macaulay-Lewis, Oxford 2017, s. 153-189. 


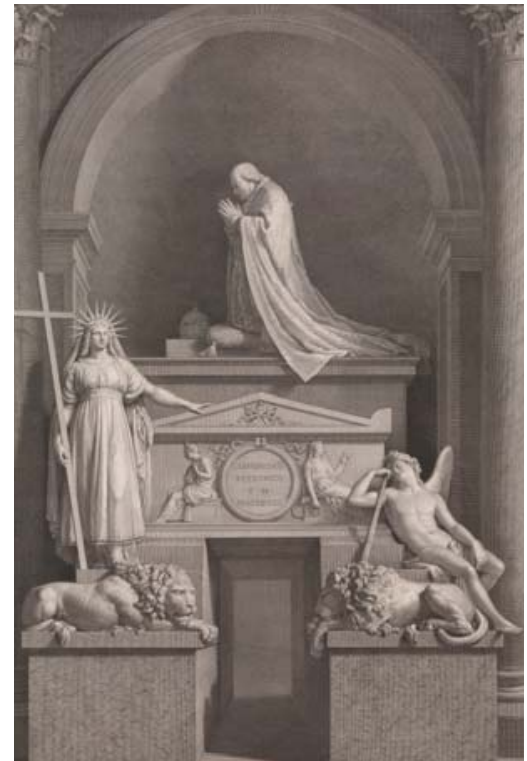

Ryc. 3. Nagrobek papieża Klemensa XIII $w$ Rzymie, ryt. R. Morghen według rysunku S. Tofanelli, ok. 1790 r. (źródło: Metropolitan Museum of Art w Nowym Jorku, nr inw. 49.116.78).

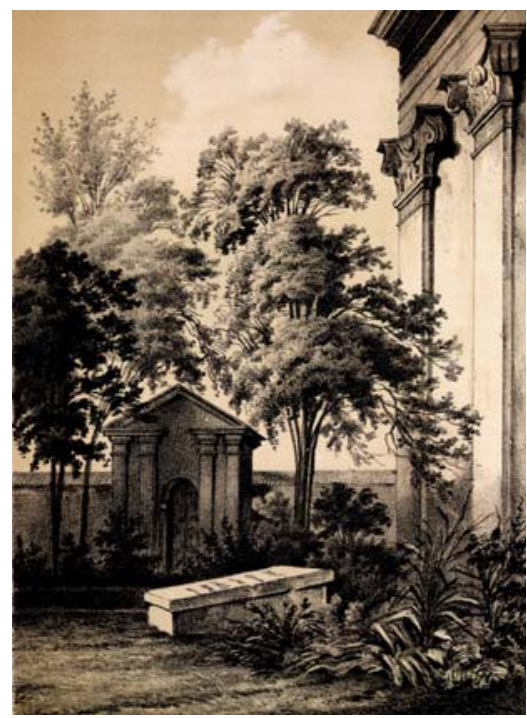

Ryc. 5. Grób Stanisława Staszica na Bielanach, litografia, rys. i lit. W. Walkiewicz, (źródło: K.W. Wójcicki, Cmentarz Powązkowski pod Warszawą, t. 3, Warszawa 1858, il. 9).

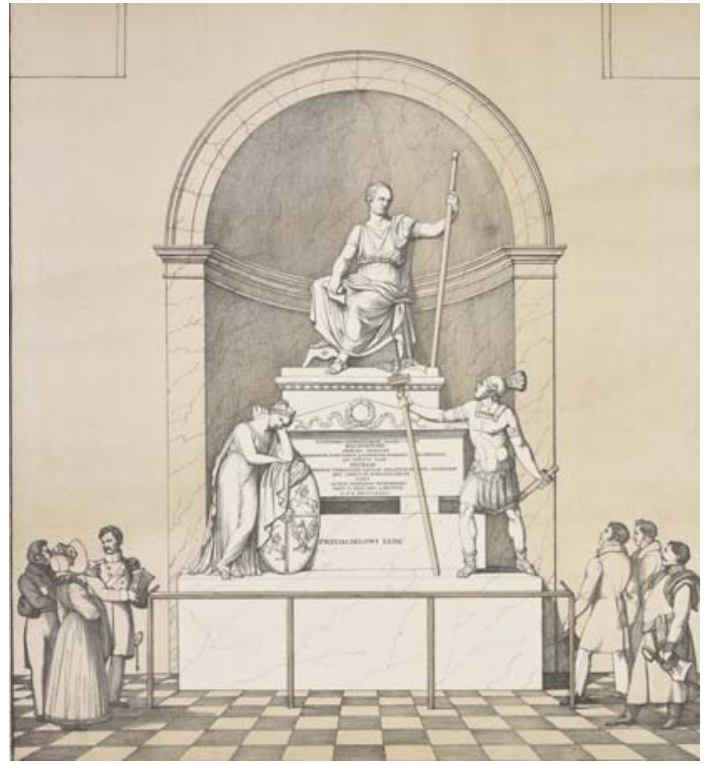

Ryc. 4. Pomnik Stanisława Małachowskiego w katedrze warszawskiej, lit. T. Vivier wg rys. L. Kauffmanna, przed 1841 r. (źródło: Biblioteka Narodowa, Zakład Zbiorów Ikonograficznych, nr inw. G.10927).

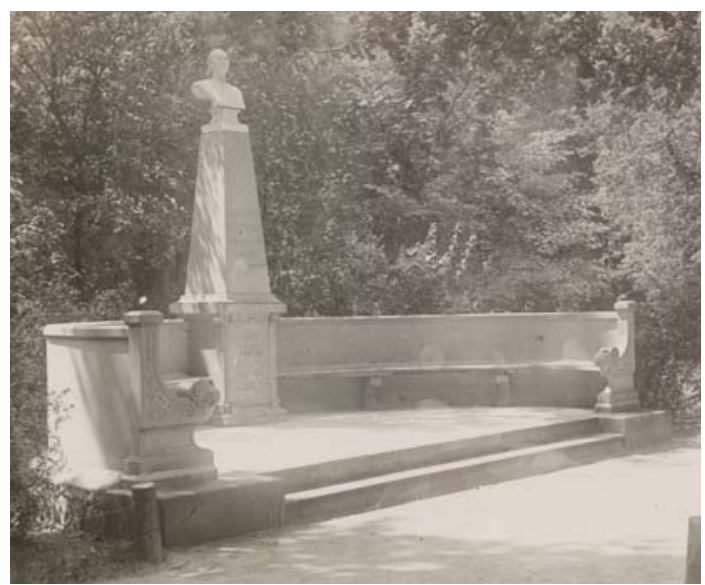

Ryc. 6. Pomnik Stanisława Staszica w Kielcach, fot. Z. Marcinkowski, przed 1932 r. (źródło: Biblioteka Narodowa, Zbiory Mieczysława Orłowicza, nr inw. F.63791). 
Bibliografia

\section{Źródła archiwalne}

Archiwum Główne Akt Dawnych w Warszawie [AGAD], zesp. Towarzystwo Królewskie Warszawskie Przyjaciół Nauk, sygn. 45, 56, 64.

\section{Źródła drukowane}

Aigner P., Budownictwo wiejskie z cegły glino-suszonej z plantami chałup wiejskich stosowne do gospodarstwa narodowego, Warszawa 1791.

Albertrandi J., O muzach, „Roczniki Towarzystwa Warszawskiego Przyjaciół Nauk” t. 1, 1802 , s. $168-219$.

Dunin-Borkowski S., Podróż do Włoch w latach 1815 i 1816, Warszawa 1820.

„Gazeta Warszawska” nr 98, 20 VI 1825 r.

Grzymała A., Głos, [w:] Zbiór mów na obchodzie pogrzebowym X. Stanisława Staszica, Warszawa 1826, s. 21-31.

Koźmian K., Pamiętniki, t. 2, Wrocław 1972.

„Kurier Warszawski” nr 19, 22 I 1826 r.

„Kurier Warszawski" nr 22, 26 I 1826 r.

Leszczyński J.N., Elegija na zgon JW. Stanisław Staszica, ministra stanu prezesa Towarzystwa Przyjaciół Nauk, Warszawa 1826.

Niemcewicz J.U., Obraz życia i czynów Stanisława Staszica, „Roczniki Towarzystwa Warszawskiego Przyjaciół Nauk" t. 20, 1828, s. 43-60.

Pancer F., Myśli o piękności w Architekturze (Dokończenie), „Pamiętnik Warszawski Umiejętności Czystych i Stosowanych" t. 3, 1829, s. 97-114, 225-238.

Potocki S.K., O sztuce u dawnych, czyli Winkelman polski, t. 1, Warszawa 1815.

Sierakowski S., Architektura obejmująca wszelki gatunek murowania i budowania, t. 1, Kraków 1812.

Skarbek F., Mowa [...] na pogrzebie ś. p. Ministra Stanu Stanisława Staszica w kościele bielańskim miana, [w:] Zbiór mów na obchodzie pogrzebowym X. Stanisława Staszica, Warszawa 1826, s. 1-21.

Staszic S., Krótki rys życia mego, [w:] S. Staszic, Pisma filozoficzne i społeczne, t. 1, oprac. B. Suchodolski, Warszawa 1954, s. 3-6.

Staszic S., Pochwała Stanisława Potockiego, „Roczniki Towarzystwa Królewskiego Warszawskiego Przyjaciół Nauk" t. 18, 1825, s. 84-134.

Staszic S., Testament, [w:] Zawadzki W., Stanisław Staszic: szkic biograficzny, Lwów 1860, s. 107-111.

Szweykowski W., Kazanie, [w:] Zbiór mów na obchodzie pogrzebowym X. Stanisława Staszica, Warszawa 1826, s. 6-21.

Ustawy Towarzystwa Królewskiego Warszawskiego Przyjaciół Nauk, Warszawa 1814.

Wójcicki K.W., Cmentarz Powązkowski pod Warszawą, t. 3, Warszawa 1858.

Wójcicki K.W., Typowe postacie i okolice dawnej Warszawy, „Biblioteka Warszawska” t. 4, 1876 , s. 315-348. 


\section{Literatura przedmiotu}

Barnett Deusner M., The Impossible Exedra. Engineering Contemplation and Convivality in Turn-of-the-Century America, [w:] Housing the New Romans. Architectural Reception and Classical Style in the Modern World, red. K. von Stackelberg, E. Macaulay-Lewis, Oxford 2017, s. 153-189, DOI 10.1093/acprof:oso/9780190272333.003.0006.

Bartnicka K., Polskie szkolnictwo artystyczne na przełomie XVIII i XIX w.: 1764-1831, Wrocław 1971.

Gajewski M., Metzell (Mecel) Ludwik Chrystian h. Trójgwiazd (1769-1848), [w:] Polski Słownik Biograficzny, t. 20, Wrocław 1975, s. 473-474.

Gajewski M., Urządzenia komunalne Warszawy: zarys historyczny, Warszawa 1979.

Gawarecki H., O dawnym Lublinie: szkice z przeszłości miasta, Lublin 1974.

Getka-Kenig M., Wystawy sztuk pięknych w Warszawie jako narzędzie polityki artystycznej władz Królestwa Polskiego w latach 1815-1830, „Folia Historiae Artium” t. 16, 2018, s. 63-78.

Główka J., Dzieje pomnika Stanisława Staszica w Kielcach, „Zeszyty Staszicowskie” t. 3, 2002, s. 237-251.

Grześkowiak-Krwawicz A., O formę rządu czy o rząd dusz? Publicystyka polityczna Sejmu Czteroletniego, Warszawa 2000.

Jabłońska-Deptuła E., Przystosowanie i opór. Zakony męskie w Królestwie Kongresowym, Warszawa 1983.

Jakubowski K., Stanisław Staszic jako geolog: refleksje rocznicowe, „Kwartalnik Historii Nauki i Techniki" t. 22, 1977, nr 2, s. 333-340.

Janowski M., Narodziny inteligencji 1750-1831, Warszawa 2008.

Jedlicki J., Szlachta, [w:] Przemiany społeczne w Królestwie Polskim 1815-1864, red. W. Kula, J. Leskiewiczowa, Wrocław 1979, s. 27-56.

Johns Ch.M.J., Ecclesiastical Politics and Papal Tombs: Antonio Canova's Monuments to Clement XIV and Clement XIII, "The Sculpture Journal” t. 2, 1998, s. 58-71, DOI 10.3828/sj.1998.2.1.8.

Kotkowska-Bareja H., Pomnik Kopernika, Warszawa 1973.

Kozakiewicz S., Malarstwo warszawskie na tle przemian gospodarczych, społecznych i politycznych w Królestwie Polskim (1815-1830), „Biuletyn Historii Sztuki”, t. 14, 1952, nr 2, s. 33-61.

Kraushar A., Towarzystwo Warszawskie Przyjaciół Nauk 1800-1832: monografia historyczna osnuta na źródłach archiwalnych. Ks. 3, Czasy Królestwa Kongresowego: czterolecie przedostatnie, 1824-1828, t. 3, Kraków 1905.

Łopaciński H., Grób Staszyca na Bielanach pod Warszawą (z powodu 80-tej rocznicy śmierci), „Nasz Kraj” t. 2, 1906, nr 5, s. 27-30.

Michalski J., Z dziejów Towarzystwa Przyjaciół Nauk, Warszawa 1953.

Mikocka-Rachubowa K., Rzeźba włoska w Polsce około 1770-1830. Katalog, Warszawa 2016.

Mościcki H., Pozgonna cześć dla księcia Józefa (pogrzeb - pomniki - pieśń i legenda), Warszawa [1922].

Polanowska J., Ogród w Warklanach - dzieło właściciela Michała Jana Borcha $i$ architekta Vincenza de Mazottiego, „Biuletyn Historii Sztuki” t. 74, 2012, nr 3-4, s. 551-599.

Rudkowski T.M., Cmentarz Powązkowski w Warszawie. Panteon Polski, Wrocław 2006. 
Stanisław Staszic i jego dzieło, red. J. Topolski, Poznań 1978.

Szacka B., Stanisław Staszic, Warszawa 1966, s. 477-498.

Tatarkiewicz W., Rzeźbiarz polskiego klasycyzmu, [w:] idem, O sztuce polskiej XVII i XVIII wieku: architektura i rzeźba, Warszawa 1966.

Wesołowski A., Nieśmiertelny $i$ dobroczynny. Historyczne badanie genezy $i$ charakteru sławy Stanisława Staszica, „Kwartalnik Historyczny” t. 125, 2018, nr 1, s. 29-63, DOI 10.12775/KH.2018.125.1.02.

dr Mikołaj Getka-Kenig, absolwent historii na Uniwersytecie Warszawskim i historii sztuki w Courtauld Institute of Art, University of London; pracę doktorską z historii obronił na Uniwersytecie Warszawskim (promotor: dr hab. Jarosław Czubaty, prof. UW); w latach 2015-2016 był adiunktem w Żydowskim Instytucie Historycznym, następnie w 2016 r. adiunktem w Instytucie Historii Nauki PAN, a w latach 2016-2019 adiunktem w Instytucie Historii Sztuki UJ. Od grudnia 2019 r. jest ponownie adiunktem w IHN PAN, a od 2021 r. również dyrektorem Muzeum Okręgowego w Sandomierzu.

e-mail: m.getka.kenig@gmail.com

Data zgłoszenia artykułu: 6 października 2020

Data przyjęcia do druku: 26 lutego 2021 